\title{
Influence of spring river flow on the recruitment of Japanese seaperch Lateolabrax japonicus into the Chikugo estuary, Japan
}

\author{
JUN SHOJI ${ }^{1}$ and MASARU TANAKA ${ }^{2}$ \\ ${ }^{1}$ Takehara Fisheries Research Station, Hiroshima University, Minato-machi 5-8-1, Takehara, Hiroshima 725-0024, Japan. \\ E-mail: jshoji@hiroshima-u.ac.jp \\ ${ }^{2}$ Laboratory of Estuarine Ecology, Centre for Education and Research of Field Science, Kyoto University, Sakyo, \\ Kyoto 606-8502, Japan.
}

\begin{abstract}
SUMMARY: The estuarine turbidity maximum (ETM) zone is considered to serve as a predation refuge for fish during the early life stages due to the high turbidity and high prey concentration. River flow can be one of the important determinants for survival of early life stages of estuarine dependent fish because it affects both the physical and biological properties of the ETM. We tested the hypothesis that fluctuation of river flow explains the variability in recruitment of Japanese seaperch Lateolabrax japonicus around the ETM region of the Chikugo River estuary, upper Ariake Bay, Japan. Japanese seaperch recruitment showed a 43.3-fold fluctuation from 1990 to 2000 and was inversely correlated with the mean daily river flow of the Chikugo River in March. The recruitment was high and variable in years of low March river flow and was poor in years of high March river flow. We conclude that high river flow potentially decreases Japanese seaperch recruitment in the Chikugo River estuary by blocking the larval migration into the river and by increasing the probability of larval dispersion to the downriver/upper bay areas, where potential predators (jellyfish and Sagitta spp.) were more abundant, and prey (Sinocalanus sinensis) availability and turbidity were lower.
\end{abstract}

Keywords: Japanese seaperch, Lateolabrax japonicus, recruitment, Chikugo River, Ariake Bay, river flow.

RESUMEN: INFLUENCIA DEL CAUDAL DEL RÍO EN EL RECLUTAMIENTO DE LA PERCA DE RÍO JAPONESA LATEOLABRAX JAPONICUS EN EL ESTUARIO DEL CHIKUGO, JAPÓN. - Se considera que la zona de máxima turbidez de los estuarios (ZMT) sirve como refugio de depredación para los peces durante sus primeros estadios de desarrollo, debido a la alta turbidez y a la concentración elevada de presas. El caudal del río puede ser uno de los determinantes importantes en la supervivencia durante estas etapas tempranas de la vida en especies de peces dependientes de los estuarios, ya que puede afectar las características físicas y biológicas de la ZMT. En el presente estudio probamos la hipótesis que la fluctuación del caudal del río explica la variabilidad en el reclutamiento de la perca de río japonesa Lateolabrax japonicus alrededor de la región de ZMT del estuario del río de Chikugo, zona superior de la bahía de Ariake, Japón. El reclutamiento de esta especie fluctuó de 1990 a 2000 y estuvo inversamente correlacionado con el caudal medio diario del río Chikugo en marzo. El reclutamiento fue alto y variable en años de bajo caudal en marzo y fue pobre en años de alto caudal en ese mes. Elevados caudales del río tienen la potencialidad de disminuir el reclutamiento de la perca de río japonesa en el estuario del río Chikugo bloqueando la migración larvaría al río e incrementando la probabilidad de dispersión larvaria hacia la parte baja del río/zonas altas de la bahía, donde los depredadores potenciales (medusas y Sagitta spp.) fueron más abundantes, y la disponibilidad de presas (Sinocalanus sinensis) y la turbidez eran más bajas.

Palabras clave: perca de río japonesa, Lateolabrax japonicus, reclutamiento, río Chikugo, bahía de Ariake, caudal del río.

\section{INTRODUCTION}

Japanese seaperch Lateolabrax japonicus is a euryhaline marine fish of commercial importance that is widely distributed in the coastal waters of Japan and Korea. The observation of high (10-fold) fluctuations in recruitment compared to those of the adult stock biomass (1.6-fold) from 1979 to 1983 
indicates a density-independent mortality occurring in the larval period of the Japanese seaperch in the upper Ariake Bay, southwestern Japan (Matsumiya et al., 1985). However, there is limited information on the mechanism of larval survival and recruitment of the species.

Larval and juvenile Japanese seaperch dominate the ichthyoplankton community in March around the estuarine turbidity maximum (ETM) of the Chikugo River, upper Ariake Bay (Matsumiya et al., 1982). The importance of the ETM zone is widely recognised in estuaries of different parts of the world because it serves as a predation refuge for fish during the early life stages due to the high turbidity, and as their feeding ground due to the high prey concentration (e.g. in St. Lawrence River (Dauvin and Dodson, 1990); in San Francisco Bay (Bennett et al., 2002), in Chesapeake Bay (North and Houde 2003); and in the Chikugo River (Shoji et al., 2006a). The larvae hatch from November to January off Kumamoto, about $50 \mathrm{~km}$ south from the mouth of the Chikugo River, and are passively transported northward by the anti-clockwise current (Hibino, 2002) prevailing in the upper Ariake Bay (Fig. 1). The larvae and early juveniles of about $15 \mathrm{~mm}$ standard length (SL) accumulate in the Chikugo River estuary in March (Hibino, 2002) and then start to migrate into the river through a selective tidal migration (Ohta, 2004). Recent surveys have demonstrated that the biological and physical properties of the ETM, such as turbidity (Shoji et al., 2006a) and spatial and temporal distribution of chlorophyll and copepods (Okazaki et al., 2005; Ueda et al, 2004), fluctuate with the variability of freshwater discharge of the Chikugo River. Growth analyses using larval otolith microstructure have shown that temperature in the northern part of Ariake Bay and larval growth were high but the recruitment was poor in the years of high winter flow (Shoji et al., 2006b). This suggests that an increase in river flow may decrease Japanese seaperch recruitment in the Chikugo River estuary through a density-independent process, as reported in other estuarine dependent fishes (Turner and Chadwick, 1972; Hayman and Tyler, 1980; Crecco and Savoy, 1984; Rulifson and Manooch III, 1990; Strydom et al., 2002; Whitefield, 2005; Shoji et al., 2006b).

In the present study, we tested the hypothesis that fluctuation in river flow affects recruitment of the Japanese seaperch in the Chikugo River estuary. Japanese seaperch recruitment and river flow was analysed for 11 years (1990-2000) to detect any possible correlation between river flow and recruitment. Physical (salinity and turbidity) and biological surveys (spatial distribution of Japanese seaperch, copepod prey and potential predators) were conducted in 2005 to demonstrate the spatial distribution of prey and predators and to evaluate the role of the Chikugo River estuary as a nursery for the Japanese seaperch.

\section{MATERIALS AND METHODS}

Annual sampling of larval and juvenile Japanese seaperch was conducted around the Chikugo River ETM in late March from 1990 to 2000. Seven sampling stations were set at an interval of about 3-5 km along the river (Fig. 1). Sampling was started at the most up-river station about 2 hours before high tide during the daytime on a day of spring tide and was

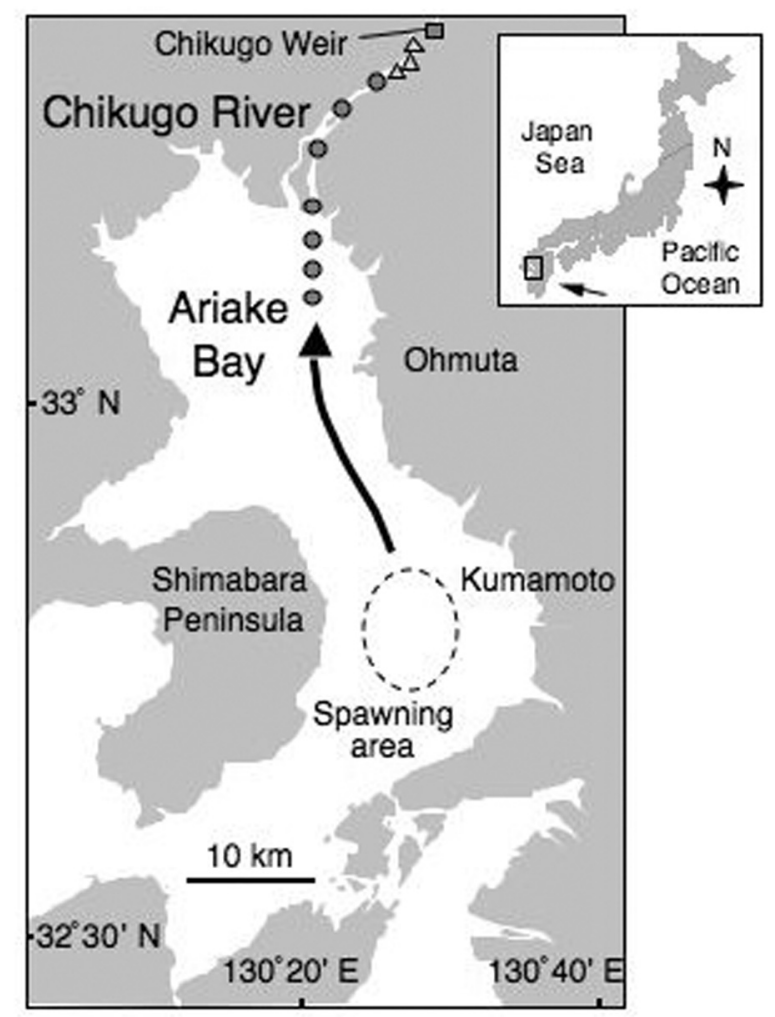

FIG. 1. - Sampling stations in the Chikugo River estuary, southwestern Japan, where biological and physical surveys were conducted in 1990-2000 and 2005. Circles indicate seven stations where Japanese seaperch larvae and juveniles were collected in March 1990-2000 and triangles indicate the stations where physical surveys, combined with samplings for the Japanese seaperch larvae and juveniles, their prey and predators, were conducted on 28 March 2005. Data on daily freshwater discharge were obtained at the Chikugo Weir (25.9 km upriver from the river mouth). Arrow shows the transportation pathway of larval Japanese seaperch from its spawning area off Kumamoto to the Chikugo River estuary. 
finished within 5 hours at the most down-river station. A conical "larva" net (1.3 m mouth diameter, $0.33 \mathrm{~mm}$ cod-end mesh) was used in order to collect larval and juvenile Japanese seaperch, which are distributed mainly in the surface layer (Matsumiya et al., 1981). Two surface tows were conducted for 10 min at a boat velocity of 2 knots (against the river flow) at each station. Fourteen ichthyoplankton samples were obtained from the 7 stations for each year. Japanese seaperch larvae and juveniles were identified using the description of Okiyama (1988), who pointed out the main differences between $L$. japonicus and L. latus, and were preserved in $95 \%$ alcohol on board. Larval and juvenile Japanese seaperch abundance (mean number of fish collected by 10 minute surface tows) in late March has been used as an annual recruitment index since the 1970s in the Chikugo estuary (Matsumiya et al., 1981). Day-to-day variability in the Japanese seaperch abundance in the Chikugo River seems to be small in late March. Our intensive (every 4 to 6 days) sampling in spring 2005 revealed that seasonal change in Japanese seaperch abundance was dome-shaped, with a peak in late March (Shoji et al., 2005a) indicating a peak in recruitment into the river at this time, as pointed out in previous studies (Matsumiya et al., 1981, 1982, 1985). Since the net was not equipped with a flowmeter during the samplings in several years from 1990 to 2000 , the mean number of larvae and juveniles collected by the 14 tows (No. tow ${ }^{-1}$ ) was used as an annual index of Japanese seaperch recruitment in order to standardise the larval and juvenile fish collection data. In spring 2005, when larval and juvenile fish samplings were conducted with a "larva" net equipped with a flow meter in the same area, mean (S.D.) water volume filtered by a tow $(\mathrm{N}=120)$ was 684.9 (64.1: present study; Shoji et al., 2006a). Daily mean freshwater discharge data for the Chikugo Oozeki Weir (25.9 $\mathrm{km}$ upriver from the river mouth: see Fig. 1) was used as a measure of river flow through the Chikugo River. To explore possible relationships between the freshwater discharge and Japanese seaperch recruitment, Pearson correlation coefficients were calculated between the monthly freshwater discharge and the recruitment index.

Physical and biological surveys were conducted at ten sampling stations on 28 March 2005. These sampling stations include the three stations that were added only for this year in a more upriver area of the Chikugo River (see Fig. 1). The salinity and turbid- ity profile was measured with an Environmental Monitoring System (YSI 650 MDS, YSI). Collection of larval and juvenile Japanese seaperch was conducted with the conical "larva" net using the same method as in 1990 to 2000 . Wet weight of jellyfish, potential predators of fish larvae (Uye and Ueta, 2004), collected by the larva net was measured on the boat. Abundance of Japanese seaperch

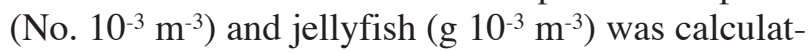
ed from the readings of the flowmeter fitted to the mouth of the net. As the Japanese seaperch starts migrating into the upriver freshwater area at ca. 17 $\mathrm{mm}$ SL (Hibino, 2002), the larvae and juveniles were divided into two size groups at $17 \mathrm{~mm} \mathrm{SL}$ and the percentage of their occurrence at each station was calculated for each size group. In order to sample the estuarine copepod, Sinocalanus sinensis, the major prey organism of Japanese seaperch $>17 \mathrm{~mm}$ SL (Hibino et al., 1999), water was sampled with a Van Dorn sampler (8L) from the surface, middle and bottom layers, filtered by a $0.05 \mathrm{~mm}$ mesh and preserved in 5\% seawater formalin. Sagitta spp., potential predators of fish larvae (Hamada, 1965), in addition to Sinocalanus sinensis, were enumerated and their abundance (No. $\mathrm{m}^{-2}$ ) was calculated for each station.

\section{RESULTS}

The Japanese seaperch recruitment index (No. tow $^{-1}$ ) showed a 43.3-fold fluctuation for the 11 years of samples, with the highest value in 2000 (68.0) and the lowest in 1992 (1.6). No significant correlation was detected between the recruitment index and the river flow for any months ( $p>0.05)$ except March (Table 1). The recruitment index was inversely correlated $(\mathrm{p}=0.011)$ with the mean daily river flow in March (Fig. 2), which fluctuated

TABLE 1. - Correlation coefficients between Japanese seaperch recruitment indices and mean daily freshwater discharge in each month from 1990 to 2000. Significant effect $(P=0.011)$ detected for March river flow is indicated by an asterisk.

\begin{tabular}{llll}
\hline Month & $\mathrm{R}^{2}$ & Month & $\mathrm{R}^{2}$ \\
\hline Jan & 0.026 & Jul & 0.060 \\
Feb & 0.113 & Aug & 0.087 \\
Mar & $0.531^{*}$ & Sep & 0.116 \\
Apr & 0.259 & Oct & 0.023 \\
May & $<0.01$ & Nov & 0.261 \\
Jun & 0.020 & Dec & 0.007 \\
\hline
\end{tabular}




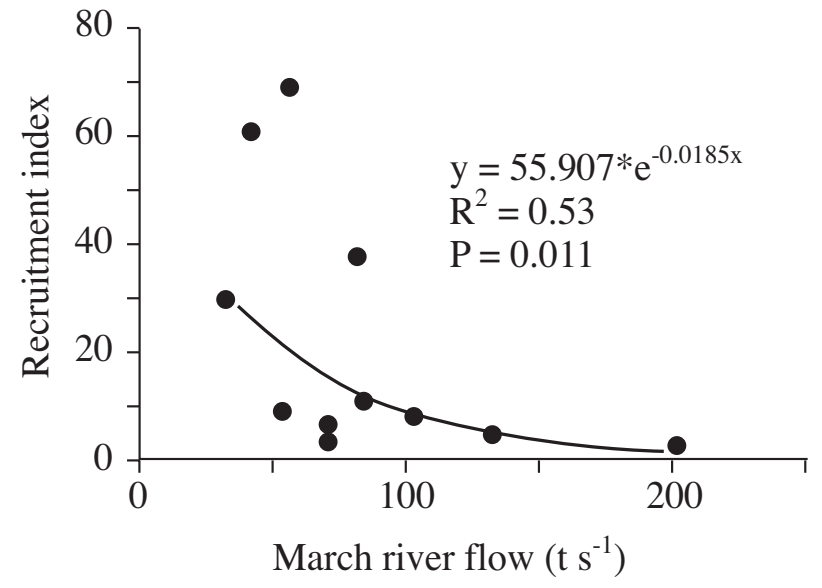

FIG 2. - Plot of Japanese seaperch recruitment index (No. tow $\left.{ }^{-1}\right)$ to mean daily freshwater discharge of the Chikugo River in March from 1990 to 2000. An exponential model was fitted to the relationship.

between $42.6 \mathrm{~m}^{3} \mathrm{~s}^{-1}$ in 1999 and $202.1 \mathrm{~m}^{3} \mathrm{~s}^{-1}$ in 1992 (mean for 1990-2000: $84.9 \mathrm{~m}^{3} \mathrm{~s}^{-1}$ ). The recruitment index was high but variable in years of low March river flow $\left(<100 \mathrm{~m}^{3} \mathrm{~s}^{-1}\right)$ and poor in years of high March river flow $\left(>100 \mathrm{~m}^{3} \mathrm{~s}^{-1}\right)$.

During the March 2005 survey, surface salinity ranged between 27.4, at the most downriver station (11 $\mathrm{km}$ downriver from the river mouth), and 0 at

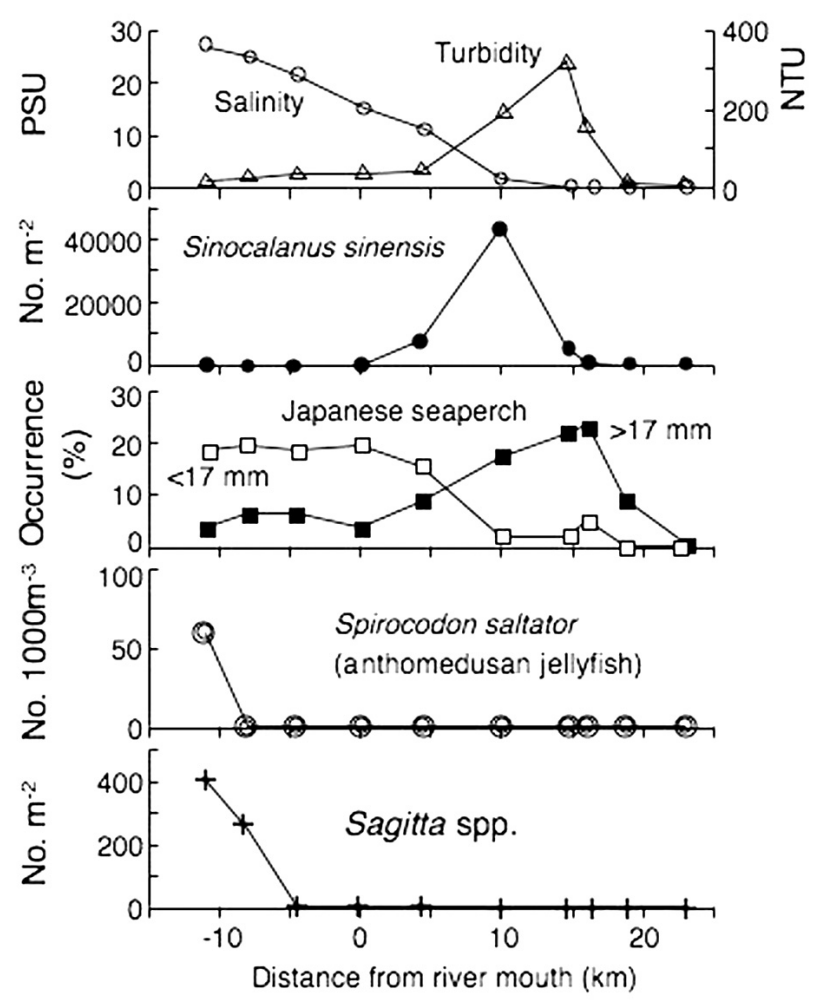

FIG 3. - Surface salinity, maximum turbidity, abundance of Sinocalanus sinensis, Japanese seaperch $(<17 \mathrm{~mm}$ and $>17 \mathrm{~mm}$, in percent occurrence), Spirocodon saltatrix, and Sagitta spp. by station on 28 March 2005 in the Chikugo River estuary. the three most upriver stations $(16.2,18.8$ and $23 \mathrm{~km}$ upriver from the river mouth) (Fig. 3). Salinity was 1.5 and 0.1 at the stations 10 and $14.7 \mathrm{~km}$ upriver, respectively. Maximum turbidity of each station exceeded 100 nephelometric turbidity units (NTU) between 10 and $16.2 \mathrm{~km}$ upriver, with the highest value (324.1 NTU) at $14.7 \mathrm{~km}$ upriver. Abundance of Sinocalanus sinensis was highest at $10 \mathrm{~km}$ upriver, corresponding to the downriver tip of the ETM. More than $85 \%$ in number of Japanese seaperch $<17$ $\mathrm{mm}(\mathrm{n}=624)$ were collected at the five most downriver stations while fish $>17 \mathrm{~mm}$ were abundant between 10 and $16.2 \mathrm{~km}$ upriver. All jellyfish collected in 2005 were identified to be the anthomedusan jellyfish, Spirocodon saltatrix, which was distributed only at the most downriver station. Sagitta spp. were distributed at the two most downriver stations, where surface salinity was $>25.3$.

\section{DISCUSSION}

The recruitment index obtained for the 11 years of sampling showed that the number of Japanese seaperch recruits was inversely correlated with March river flow of the Chikugo River. The mechanism of how high river flow reduces fish recruitment differs among ecosystems and fish species. Hayman and Tyler (1980) found that cohort strength of Dover sole Microstomus pacificus was inversely correlated with the Colombia River discharge in February, March, and April, the time of settlement. Coastal storms that are associated with high river flow during this season are considered to decrease food supply and damage the larvae. Crecco and Savoy (1984) found that river flow was significantly correlated with American shad Alosa sapidissima yearclass for June, the period when most shad larvae emerge in the Connecticut River. They suggested that the river flow affected shad larvae survival by controlling zooplankton densities, river hydrography and larval feeding success. Rulifson and Manooch III (1990) analysed recruitment of juvenile striped bass Morone saxatilis in the Roanoke River and reported that the juvenile abundance was best in years of low to moderate river flow and poor in years of very low and high river flow. River flow was considered to influence spawning behaviour of adult fish, egg and larval transport downstream, zooplankton distribution and larval feeding in the Roanoke River. 
In the Chikugo River estuary, high winter river flow has been reported to be associated with high temperature (Shoji et al., 2006b). In addition, production of copepods - major prey organisms of the larval Japanese seaperch - in the upper Ariake Bay increased when the river flow increased (Okazaki et al., 2005). These observations seem to indicate that environmental conditions are more favourable for feeding and growth of Japanese seaperch larvae and juveniles in high flow years. However, analysis on the larval growth (Shoji et al., 2006b) and recruitment abundance of the Japanese seaperch from 1990 to 2000 (present study) indicated that recruit was poor in years of high winter river flow even though the temperature experienced by the larvae and the back-calculated larval growth was high in the high flow years (Shoji et al., 2006b). A more direct, density-independent mechanism affected by the physical properties of the habitat is suggested to control Japanese seaperch recruitment and lead to its high variability, as found in other estuaries (Whitfield, 2005).

Japanese seaperch larvae are abundant in the surface layers and spend the planktonic stage in the upper Ariake Bay, passively transported northward by the residual current in the upper bay area (before reaching the estuary and starting upriver migration: Matsumiya et al., 1981; Hibino, 2002). The possibility of successful larval migration into the river is therefore highly dependent on the physical structures of the surface waters of the estuary and upper bay area. Since turbidity and prey concentration are higher in the upriver area of the Chikugo River, earlier migration into this area would provide the larvae with more favourable conditions for survival due to low predation and high prey availability (Fig. 4). An increase in the river flow may delay larval migration since the location of the 1 psu isohaline - the index of location of the low salinity area-in the Chikugo River has been reported to correlate with the mean daily river flow for the previous five days (Kanematsu, 2005). An increase in the vulnerability to starvation- and predation-related mortality due to a delay in migration into the river can occur because turbidity and prey concentration are low and potential predators are more abundant in the downriver area/upper bay area (Fig. 4). The longer Japanese seaperch remain in the upper bay area, the greater their accumulated larval mortality is (Houde, 1987).

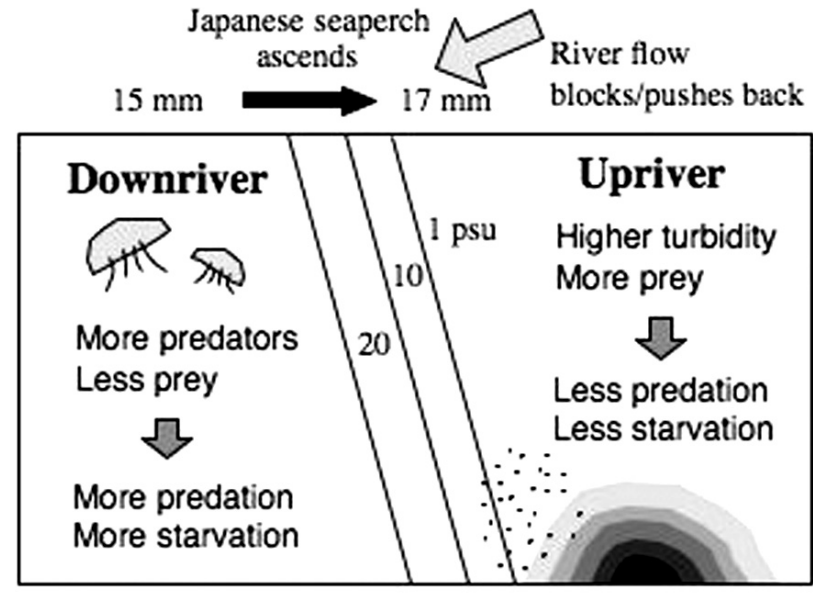

FIG 4. - Schematic drawing of environmental condition of the Chikugo River estuary as a nursery for Japanese seaperch. Black dots indicate aggregation of Sinocalanus sinensis, the major prey organism of Japanese seaperch, and grey areas the estuarine turbidity maximum zone.

Even if the larvae successfully migrated into the river, Japanese seaperch are vulnerable-especially under high flow conditions - to dispersion from the upriver area to the downriver area/upper bay area. Japanese seaperch are distributed mainly in the surface layer after the river migration and move back and forth with the surface water along the longitudinal direction of the river corresponding to the tidal movement (Matsumiya et al., 1981; Ohta, 2004). In the Chikugo River, in addition, high flows easily transform the well-mixed estuary to a salt-wedge estuary (Ueda et al., 2004; Shoji et al., 2006a). Based on these observations, we conclude that an increase in March river flow reduces Japanese seaperch recruitment by reducing the possibility of larval migration into the river during the pre-recruit period and increasing the possibility of larval downward dispersion during the post-recruit period.

\section{ACKNOWLEDGEMENTS}

The authors are grateful to T. Sakemi, K. Sakemi, S. Koga, T. Ueda and former students and staff of our laboratory, who greatly contributed to the field sampling. Dr. T. Ohta, of the Tottori Prefecture Fisheries Research Centre, and Dr. Y. Yamashita, of the Field Science Education and Research Centre, Kyoto University, provided valuable comments. This study was supported in part by Grants from the Ministry of Education, Culture, Sports and Science and from the Nippon Life Insurance Foundation. 


\section{REFERENCES}

Bennett, W.A., W.J. Kimmerer and J.R. Burau. - 2002. Plasticity in vertical migration by native and exotic estuarine fishes in a dynamic low salinity zone. Limnol. Oceanogr., 47: 1496-1507.

Crecco, V.A. and T.F. Savoy. - 1984. Effects of fluctuations in hydrographic conditions on year-class strength of American shad (Alosa sapidissima) in the Connecticut River. Can. J. Fish. Aquat. Sci., 41: 1216-1223.

Dauvin, J.C. and J.J. Dodson. - 1990. Relationship between feeding incidence and vertical and longitudinal distribution of rainbow smelt larvae (Osmerus mordax) in a turbid well-mixed estuary. Mar. Ecol. Prog. Ser., 60: 1-12.

Hamada, T. -1965 . Perspectives on the predator-prey relationships between Sagitta crassa Tokioka and larval, juvenile and adult Japanese sand eel Ammodytes personatus. Bull Hyogo Pref. Fish. Exp. Stn. Spec. Publ., 3: 1-6.

Hayman, R.A. and A.V. Tyler. - 1980. Environment and cohort strength of Dover sole and English sole. Trans. Am. Fish. Soc., 109: 54-70.

Hibino, M. - 2002. Early life history diversity of the Ariake population. In: M. Tanaka and I. Kinoshita (eds.), Temperate Bass and Biodiversity-New Perspective for Fisheries Biology, pp. 65-78. Tokyo, Koseisha Koseikaku.

Hibino, M., H. Ueda and M. Tanaka - 1999. Feeding habits of Japanese temperate bass and copepod community in the Chikugo River estuary, Ariake Sea, Japan. Nippon Suisan Gakkaishi, 65: 1062-1068.

Houde, E.D. - 1987. Fish early life dynamics and recruitment variability. Am. Fish. Soc. Symp., 2: 17-29.

Kanematsu, Y. - 2005. Distribution and survival of egg, larval and juvenile Coilia nasus in down Chikugo River and Ariake Bay, Japan. B.A. thesis, Univ. Kyoto.

Matsumiya, Y., S. Kaminosono, M. Tanaka, A. Shirota and T. Yamashita. - 1981. Studies on the juvenile Japanese sea bass in the Chikugo estuary of Ariake Bay - 1. Bull. Jap. Soc. Fish. Oceanogr., 38: 6-13.

Matsumiya, Y., T. Mitani and M. Tanaka. - 1982. Changes in distribution pattern and condition coefficient of the juvenile Japanese sea bass with the Chikugo River ascending. Nippon Suisan Gakkaishi, 48: 129-138.

Matsumiya, Y., H. Masumoto and M. Tanaka. - 1985. Ecology of ascending larval and early juvenile Japanese sea bass in the Chikugo River estuary. Nippon Suisan Gakkaishi, 51: 1955-1961.
North, E.W. and E.D. Houde. - 2003. Linking ETM physics, zooplankton prey, and fish early-life histories to striped bass Morone saxatilis and white perch $M$. americana recruitment. Mar. Ecol. Prog. Ser., 260: 219-236.

Ohta, T. - 2004. Ecological studies on the river ascending migration of Japanese sea bass Lateolabrax japonicus in Ariake Bay, on the basis of otolith information. PhD thesis, Univ. Kyoto.

Okazaki, Y., Y. Hosoe, Y. Nonaka and H. Nakata. - 2005. Spatial and temporal distribution of copepod nauplii in Ariake Bay. Bull. Jap. Soc. Fish. Oceanogr., 69: 10-17.

Okiyama, M. - 1988. An atlas of the early stage fishes in Japan. Tokai Univ. Press, Tokyo.

Rulifson, R. and C.S. Manooch III. - 1990. Recruitment of juvenile striped bass in the Roanoke River, North Carolina, as related to reservoir discharge. North Am. J. Fish. Manag., 10: 397-407.

Shoji, J., K.W. Suzuki and M. Tanaka. - 2006a. Effect of tide and river flow on physical and biological properties in the estuarine turbidity maximum of the Chikugo River estuary during spring in 2005: evaluation as a nursery for the estuarine-dependent fish, Japanese seaperch Lateplabrax japonicus. Bull. Jap. Soci. Fish. Oceanogr., 70: 31-38.

Shoji, J., T. Ohta and M. Tanaka. - 2006b. Effects of river flow on larval growth of Japanese seaperch Lateolabrax japonicus in the Chikugo River estuary, upper Ariake Bay. J. Fish Biol. (in press).

Strydom, N.A., A.K. Whitfield and A. W. Paterson. - 2002. Influence of altered freshwater flow regimes on abundance of larval and juvenile Gilchristella aestuaria (Pisces: Clupeidae) in the upper reaches of two South African estuaries. Mar. Freshw. Res., 53: 431-438.

Turner, J.L. and H.K. Chadwick. - 1972. Distribution and abundance of young-of-the-year striped bass, Morone saxatilis, in relation to river flow in the Sacramento-San Joaquin Estuary. Trans. Am. Fish. Soc., 3: 442-452.

Ueda, H., A. Terao, M. Tanaka, M. Hibino and S. Islam. - 2004. How can river-estuarine planktonic copepods survive river floods? Ecol. Res., 19: 625-632.

Uye, S. and U. Ueta. - 2004. Recent increase of jellyfish populations and their nuisance to fisheries in the Inland Sea of Japan. Bull. Jap. Soci. Fish. Oceanogr., 68: 9-19.

Whitfield, A.K. - 2005. Fishes and freshwater in southern African estuaries - A review. Aquat. Liv. Resour., 18: 275-289.

Received October 27, 2005. Accepted May 30, 2006.

Published online September 26, 2006. 